\title{
The role of critical qualitative research in educational contexts: A Canadian perspective
}

\section{O papel da pesquisa qualitativa crítica em contextos educacionais: uma perspectiva Canadense}

\author{
Susan Tilley*
}

\begin{abstract}
In this paper, the author discusses the qualitative shift in educational research from a historical dependence on positivist and post-positivist frameworks to a proliferation of research situated within a qualitative, interpretivist paradigm. Offering a Canadian perspective, the author situates the discussion of critical qualitative research in relation to the growing neoliberal influence on educational contexts and policy decisions. She argues the need for educational researchers to conduct critical qualitative research to explore the complex issues that educators face to ensure that all students have access to equitable educational experiences, not only those students who represent the Canadian dominant white, middle-class norm. The author introduces a strand of qualitative research focused on the experiences of black, racialized and Indigenous students to illustrate the need for critical research that privileges local knowledge and human experience, while also taking into account the dominant institutional structures that shape educational experience. Although acknowledging the place of quantitative research in the educational domain, she argues that critical qualitative research is essential to understand the experiences of marginalized students in educational contexts and to provide space for voices not available in the quantitative domain. The author concludes that critical qualitative research has an important role to play in informing new directions in educational practices and policies that will help to ensure a socially just education for all students, regardless of backgrounds.
\end{abstract}

Keywords: Critical qualitative research. Interpretivist paradigm. Educational practices.

*Brock University, Ontário, Canadá. E-mail: susan.tilley@brocku.ca. https://orcid.org/00000002-8466-7587. 


\section{RESUMO}

Neste artigo, a autora discute a mudança qualitativa na pesquisa educacional de uma dependência histórica de quadros positivistas e pós-positivistas para uma proliferação de pesquisa situada dentro de um paradigma qualitativo interpretativista. Oferecendo uma perspectiva canadense, a autora situa a discussão da pesquisa qualitativa crítica em relação à crescente influência neoliberal em contextos educacionais e decisões políticas. Ela argumenta sobre a necessidade de pesquisadores educacionais conduzirem pesquisas qualitativas críticas para explorar as complexas questões que os educadores enfrentam para garantir que todos os alunos tenham acesso às experiências educacionais equitativas, não apenas àqueles estudantes que representam a maioria Canadense, brancos com padrões da classe média. A autora apresenta uma vertente de pesquisa qualitativa voltada para as experiências de estudantes negros, Indígenas e os com demais descriminações raciais para ilustrar a necessidade de uma pesquisa crítica que privilegie o conhecimento local e a experiência humana, levando em conta também as estruturas institucionais dominantes que moldam a experiência educacional. Embora reconheça o lugar da pesquisa quantitativa no domínio educacional, ela argumenta que a pesquisa qualitativa crítica é essencial para compreender as experiências de alunos marginalizados em contextos educacionais e para fornecer espaço para vozes não disponíveis no domínio quantitativo. A autora conclui que a pesquisa qualitativa crítica desempenha um papel importante na informação de novos rumos nas práticas e políticas educacionais que ajudarão a garantir uma educação socialmente justa para todos os alunos, independentemente de suas origens.

Palavras-chave: Pesquisa qualitativa crítica. Paradigma interpretativista. Práticas educativas.

\section{Introduction}

As we move further into the 21 st century, a major emphasis of educational inquiry in Canada continues to be on social justice and equity issues, in K-12 and postsecondary education. I argue in this paper that to explore the complex issues that educators and educational authorities face to provide a socially just education for all students, educational researchers need to conduct qualitative research situated within an interpretivist paradigm and informed by critical theoretical perspectives. Educational researchers in faculties of education, who inquire into teaching and learning along the trajectory K-12 to postsecondary, 
are well-positioned to conduct this research. This is especially true of those researchers who have taken a qualitative turn from earlier times when positivist and postpositivist frameworks were dominant in the academy (PAGE, 2000). Faculties of education continue to be, as Paul and Marfo (2001, p. 527) suggested, "[...] epistemologically diverse research communities, with an increasing number of faculty members committed to qualitative approaches to research."

Historically, research in educational contexts has been predominantly influenced by a positivist, post-positivist paradigm and quantitative methodology and methods have provided data to address important educational questions (LANGEMANN, 2000; PAUL \& MARFO, 2001). The struggle for qualitative, interpretivist methodology to find a prominent place in educational research, began in the shadows of the influence of this positivist, post-positivist paradigm. However, decades have passed since qualitative methodologies and methods have found a home in faculties of education and educational contexts. There is a recognition of the value of qualitative research that "involves an interpretive, naturalistic approach to the world" to support deep exploration of individuals' and communities' experiences of educational systems, and to produce findings that can inform educational administrators and policy makers.

Qualitative research is a situated activity that locates the observer in the world. [...] [It] involves an interpretive, naturalistic approach to the world. [...] qualitative researchers study things in their natural settings, attempting to make sense of or interpret phenomena in terms of the meanings people bring to them. (DENZIN \& LINCOLN, 2011, p. 3)

There are many handbooks that offer historical framings of the development of the field of qualitative research and complex perspectives on critical moments as it evolved (DENZIN \& GIARDINA, 2006; DENZIN \& LINCOLN, 2011, 2005). The comprehensive body of literature about qualitative methodologies and methods and academic journals reporting on qualitative research, plus the increase in journals specifically focused on qualitative methodologies and methods, reflect the advancements in qualitative inquiry (e.g., Qualitative Inquiry, International Journal of Qualitative Studies in Education, Qualitative Methods). Researchers in academic spaces have moved beyond the historical, binary-focused debates on qualitative versus quantitative methodologies, or at the least, these debates have subsided (LINCOLN \& GUBA, 1985; LINCOLN, LYNHAM \& GUBA, 2011). 


\title{
Background
}

I write from my location working in the Faculty of Education in a university in Ontario, Canada. Previous to my academic position, I worked for 15 years in public school contexts. The areas I have explored as an educational researcher have taken shape as a result of my work as a teacher, in schooling contexts, and my continuing experiences as an instructor in university classrooms. Through both teaching and research, I continue to explore questions related to diversity, equity and social justice issues in education (TILLEY, 2006; TILLEY \& POWICK, 2015).

Geographical, political and philosophical positionings influence educational researchers' methodological choices. My research questions have been best addressed through a qualitative methodological lens. I feel at home in the interpretivist realm that has post-modern, post-structural leanings (TILLEY, 2016). However, my comfort level has changed in recent years as I struggle, as do many of my colleagues in other local and global contexts, to teach and research in an institution that is becoming ever more entrenched in a neoliberal business model.

\begin{abstract}
Neoliberalism is both an orientation to economic policy and a philosophy that has become widespread in the U. S. and other western societies over the last 3 decades. We can see neo-liberal philosophical orientations in the way neo-liberalists view the market as a mode of social organization. Market imperatives, not ethical or humane considerations drive social, political, economic, and educational policy in neo-liberalism (KINCHELOE, 2008, p. 24).
\end{abstract}

The length of this paper precludes a comprehensive discussion of the effects of neoliberalism on postsecondary institutions and education; a body of literature, which continues to grow, is already available (JOSHEE, 2009; PICOWER, 2011). Many people who have been situated in Canadian universities, for a number of years, are struggling to find space to teach and research in the neoliberal environment that has become their home. This environment intersects with the world outside academe. "Ontario is now open for business," is the newly elected Premier of Ontario's refrain articulating his promise of support for the business sector. Some would argue that this support will come at the cost of other domains, including education in Ontario. For those of us teaching 
and researching from a social justice standpoint and postmodern, postcolonial lens, we are pushing against the trends of neoliberalism.

Although I write with the Canadian context in mind, I hope that what I write will speak to others situated in the global terrain.

\section{Critical perspectives}

Qualitative researchers come to our work with theoretical perspectives already in place, some are purposeful and recognized, while others remain unacknowledged but present, in the backs of our minds. In this paper I speak to the value of qualitative research, informed by critical theoretical perspectives, in exploring the experiences of students and teachers who have struggled, in various ways, to be successful in the educational domain. "Critical theory is, above all else, a way to ask questions about power. Who has it? How did they get it ...keep it? What are they doing with it? How do their actions affect the less powerful? How might things be otherwise?" (HINCHEY, 2010, p. 17)

Educational researchers utilizing a critical theoretical framework often focus on questions about what has become normalized in schools and classrooms and how power is exercised in public school and postsecondary contexts, while taking into account the social and political terrain. Researchers from post perspectives (postmodern, poststructural, and postcolonial) have been constructing research questions about dominant institutional structures that shape educational experience while also making central, and privileging, local knowledge and human experience. Foucault (1980) argued for the importance of "local popular knowledges...disqualified knowledges" to the work of criticism: "It is through the re-appearance [or honouring] of this knowledge, of these local popular knowledges, these disqualified knowledges, that criticism performs its work" (p. 82). To make sense of experiential data, micro actions, and local knowledge, researchers consider them in light of these overarching structures.

Verkuyten (2003) suggests: "There is a tendency to treat existing power relations and domination as a priori, as a backdrop for analysis, and thereby as unproblematic and given, whereas the phenomenon selected for analysis ... is made problematic." (p. 139). In critical qualitative research, power relations and domination are brought to the foreground not left as a backdrop. Qualitative research that critiques meta structures, that makes them problematic, while producing data that uncover local, experiential knowledge has helped put flesh on the bones of narratives that uncover unjust educational structures, policies 
and practices. Researchers in the critical tradition are practicing the skepticism Prasad (2005) describes "crafting research in the critical theory tradition requires skepticism about the innocence of social and institutional practices, however innocuous and common place they might seem" (p. 153).

The section that follows provides a brief exploration of the interpretivist, qualitative paradigm and educational research, providing context for the discussion that follows.

\section{Section 2: Educational research and the qualitative paradigm}

The turn of many researchers, in faculties of education, to qualitative methodologies and methods has been, in part, a result of their desire to explore complex educational issues that resist explanation through the historically dominant post-positivist lens. Qualitative interpretivist research is no longer understood as a poor cousin to post-positivist quantitative work and educational researchers are valuing the usefulness of a qualitative research lens on teaching and learning. Researchers situated within an interpretivist paradigm are distanced from conventional positivist assumptions, not driven by the objective of hypothesis testing. Rather, the goal is to understand the phenomenon under study. Qualitative researchers, while serving as the primary research instrument, produce knowledge that is contextually sensitive and influenced by a variety of factors. They explore their research questions from the perspective that knowledge is value-laden, partial and always contestable and that multiple truths circulate in research contexts. They are interested in researching meanings participants themselves assign to their own experiences (SEE LINCOLN, LYNHAM \& GUBA, 2011 for comprehensive discussion of inquiry paradigms).

Critical qualitative methodologies can provide a useful framework to examine structural issues related to the privileging of dominant discourses in education. They are necessary to explore the experiences of individuals and groups who have faced marginalization and inequitable treatment within educational systems and to critique the policies and procedures in place. Denzin \& Lincoln (2011) describe an "avowed humanistic and social justice commitment to study the social world from the perspective of the interacting individual [...]" at the core of qualitative research and critical researchers' intentions (p. 13).

Qualitative researchers acknowledge the importance of context and the value of understanding experience, producing knowledge not accessible through positivistic, quantitative frameworks. They are able to uncover knowledge 
related to the whys of the phenomena explored and can provide data useful to administrators and policy makers who make decisions that help to maintain or to change the status quo of educational systems.

Quantitative data generates objective, conclusive and numerical figures. On the other hand, qualitative data is broad, non-statistical, exploratory, and descriptive. So while quantitative data is crucial for recording facts about a group of people such as ethnicity, occupation, or level of poverty etc., collecting qualitative data will reveals insights into their opinions, hopes, and motivations and reasons (RESEARCHING WITH CASH TRANSFERS, 2016).

Historically, educational researchers have drawn on well-established traditions from a variety of disciplines to design qualitative projects to explore their critical questions. Drawing from anthropology, sociology and other social sciences, educational researchers have conducted educational ethnographies for many years (GOETZ \& LECOMPTE, 1984; HAMMERSLEY, 1990). Ethnographies have been conducted in individual schools (YON, 2000) and in schools in non-traditional educational contexts (e.g., prison school, TILLEY, 1998). The work of Canadian scholar Dorothy Smith (2005) has spawned many institutional ethnographies.

More currently, educational researchers continue to use traditional ethnographic methods including observation, interviews, field notes, and collection/ construction of visuals to collect data for their critical qualitative research projects. However, ethnographic research has taken innovative forms, providing alternative ways to explore critical educational questions (performance ethnography, DENZIN, 2003; HAMERA, 2011), duo ethnography (SAWYER $\&$ NORRIS, 2015). This move to the innovative can be seen across a number of interpretive methodologies and methods (GALLAGHER, 2008), including Indigenous methodologies (DENZIN; LINCOLN; TUHIWAI SMITH, 2008). Critical methodologies, such as participatory action research, have expanded on more traditional ethnographic criteria to include action and change (KAPOOR e JORDAN, 2009; KINDON; PAIN e KESBY, 2010). Collaboration with participants and participant and community-based action research are also part of this critical tradition (JARDINE e JAMES, 2012; SETHI, 2014). This multiplicity of interpretivist communities and methodologies contributes to making visible voices absent in quantitative traditions (GINWRIGHT, 2008). This is especially true in the case of youth and children. "Increasingly [...] researchers 
value children's perspectives, seeing children as active agents in constructing and communicating their own realities [...]" (SCHELBE, et al., 2015, p. 505).

Questions of representation, reciprocity, ethics and participant rights have grown as part of this turn to the qualitative. The rights of youth and other vulnerable populations, in educational research, are an emphasis in the continuing articulations and critique of research ethics (TILLEY, POWICK-KUMAR e RATKOVIC, 2009). Obtaining informed consent and ensuring participation is voluntary pose a challenge as does assessing the degree of vulnerability of youth participants (LOUTZENHEISER, 2007). In Canadian school systems, students experiencing high degrees of marginalization are often Indigenous, black and racialized youth who have suffered discrimination and disproportionate rates of suspension and expulsion (MCMURTRY, 2009). In order to understand this population imbalance, researchers must "capture the mosaic of experiences and textured realities of young people's lives" (GINWRIGHT, 2008, p. 14).

A growing literature in youth methods argues that researchers need to question the appropriateness of conducting research on youth, rather than with youth (SULEIMAN, SOLEIMANPOUR, LONDON, 2006). The intention is not only to collect information or to make youth voices visible but to engage youth "... in a process of analysis and reflection that can lead to the ability to participate in decisions" (JARDINE e JAMES, 2012, p. 1). Youth involved in critical qualitative research as co-researchers are building skills and knowledge useful outside the research context, including in the social and political domain.

The issues qualitative researchers explore have changed over the decades and across educational contexts. Questions reflect the growing diversity of many countries' populations and the complexities of providing education across local and global communities. The application of "multiple epistemologies and methodologies" to research in this area is clearly needed. "Indeed, multiple kinds of knowledge, produced by multiple epistemologies and methodologies, are not only worth having but also demanded if policy, legislation, and practice are to be sensitive to social needs" (LINCOLN e CANNELLA, 2004, p. 7).

Educational researchers viewing the world from a postmodern/postcolonial lens feel comfortable addressing their critical questions using methodologies and methods emerging from a qualitative, interpretivist paradigm. They continue to place value on asking questions that highlight the hold of dominant group values in educational contexts and the social reproduction that continues in schools. They research the experiences of students who spend a large portion of their lives in schools and postsecondary institutions, learning the Eurocentric foundational knowledge, the dominant curricular canon, to the exclusion of a multiplicity of knowledges, including Indigenous. These researchers conduct qualitative studies to understand the struggles of people to become educated in 
the face of the hegemonic discourse of meritocracy that continues to exist in educational institutions in Canada and other geographical contexts (BANKS, 2009). They challenge those in charge, at micro and meta levels, to make change.

\section{Meta-structure: Multicultural education}

What critical qualitative research can offer is an exploration of educational issues that are contextualized in relation to meta-structures and informed by experiential data and local knowledge. I use the meta structure, multicultural education, to frame the following discussion of the need for critical qualitative research in educational contexts. In Canada, multicultural discourses continue to influence decisions made related to educational institutions, teaching and learning. Banks provides the following definition that captures the main elements of the concept in the North American context:

Multicultural education is an approach to school reform that is designed to actualize educational equality for students from diverse, racial, ethnic, culture, social-class, and linguistic groups. It also promotes social justice. A major goal of multicultural education is to reform schools, colleges, and universities so that students from diverse groups will have equal opportunities to learn (BANKS, 2009, p.13).

While the definition captures some elements of what has become known as multicultural education in Canada, major criticisms of the resulting implementation of the principles and practices of the concept continue.

Canada prides itself on its multiculturalism and acceptance of difference (consider the metaphoric representation of Canada as a mosaic of different peoples and cultures living in harmony). The Liberal government of Canada formalized a policy of multiculturalism in 1971 (MOODLEY, 2001). Since that time, a collection of policies has supported the concept of multicultural education emerging from Canada's multicultural society (JOSHEE, 2009).

Researchers in faculties of education have been focused on questioning the various attempts of educational authorities and policy makers to deal with diversity issues in education and to address the systematic marginalization of students living out their educational lives in Canadian systems. Multicultural 
education has been implemented, to varying degrees, as a means of addressing educational inequities and injustice in the educational system (SEE MOODLEY, 2001, for a comprehensive historical perspective). Although the multicultural education agenda continues to be supported, this vision of education has been critiqued for, among other things, its oversimplification and under-theorization of culture and its surface-level attempts to understand and be respectful of difference (ST. DENIS, 2007). This concept of multiculturalism is agreeable to individuals who dwell in a world framed by a liberal, white, humanist perspective and where the discourse of meritocracy, colour-blindness and equality are deeply embedded.

Critics point to the work to be done to ensure students, who are not part of the western, white, middle-class heterosexual norm, have access to the same education as other students and multicultural education is left wanting in the advancement of this critical project. Related to the Canadian context Gosh \& Abdi (2013) write:

Multiculturalism is a controversial issue that is hotly debated at the educational level. It is an arena of power struggles, in which different constituencies struggle with their different issues... They [existing concepts of multiculturalism] have failed to question the norm of whiteness, and how white culture has maintained its dominance by being invisible (p. 32).

In Canada, an important role of critical qualitative research has been to point to the many students from non-dominant groups who struggle to find space in educational contexts that are fueled by White western ideologies and frameworks to the exclusion of all others and manned by teachers who continue to reflect the dominant white, middle-class norm (LEVINE-RASKY, 2012). Schick \& St. Denis (2005) consider the limitations of a multicultural approach from the perspective of race and systematic whiteness.

The multicultural approach to education sanctions ignorance of racializing systems including the production of white identities and the taken-for-granted of racial dominance. Because whiteness in schools is not usually talked about, it is consequently recentered as an invisible standard of success against which others are marked [...] (p. 308). 
A prominent critique of Eurocentrism and structural whiteness is embedded in many of the critical qualitative studies that look to participants' experiences and local knowledge to understand the workings of the structures. These studies make visible the limitations of a dependence on multicultural education to create equitable opportunities for all students and argue for the necessity of understanding whiteness as an embedded structure that can have life altering effects on students' lives. "The effects of whiteness can be observed in social life and institutions. Its structural impacts are overwhelming in scope and sobering in their human cost" (LEVINE-RASKY, 2012, p. 92). They emphasize the need to provide opportunities to hear the voices of racialized and Indigenous voices to learn about structural whiteness. Even though the critique of multicultural discourses and education persist, many educators continue to work within the framework of multiculturalism in Canada.

\section{Section 3: Qualitative research: A view into the world of educatio- nal experience}

In Canada, prominent in the research is a qualitative strand of work focused on building knowledge about the experiences of black, Indigenous, racialized and working-class students, in K-12 and postsecondary education. This strand consists of clusters of interconnected issues. A critical issue is epistemology-what counts as knowledge and who decides and whose knowledge is included in public school and postsecondary curriculum. Critical researchers and especially Indigenous scholars are trying to build knowledge on ways to decolonize curriculum and educational systems (BATTISTE, 2013; COTE-MEEK, 2014). Research on multicultural education and anti-racist and anti-oppressive pedagogies is a clustered emphasis.

The section that follows explores how critical qualitative research contributes to understanding issues of curriculum and pedagogy. Researchers in faculties of education are asking questions related to curricular knowledge and teaching pedagogies using qualitative research to explore how curriculum decisions and pedagogical beliefs and practices help maintain or disrupt the inequities students experience within the larger systems. 


\section{Curriculum: What knowledge counts?}

The assumed absence of racism in Canada is refuted by a long history of discriminatory government policies and practices, including racial segregation in schools, forced assimilation of First Nations Canadians and racialized immigration restrictions... For various reasons, such unsavoury aspects of Canadian history have been excluded or downplayed in current social studies school materials, and by many in political and administrative positions (LUND, 2003, p. 4-5).

Qualitative methodologies, with their critical theoretical perspectives, emphasis on experiential knowledge and attention to meta-structures, are important in exploring critical socio-cultural research questions related to curriculum and pedagogy. Research questions focused on the ways in which traditional Eurocentric knowledge is maintained in educational contexts exemplifies this type of methodological exploration. Exclusion of important historical and cultural knowledge in curriculum is well-documented in critiques of official school knowledge including the "unsavoury aspects of Canadian history" to which Lund (2003) above refers.

\section{Racism and the curriculum}

Qualitative researchers have collected data from students who have experienced marginalization and racism in public school and postsecondary education. These students describe questioning the Eurocentric curriculum and the lack of representation, and at times mis/representation of their identities in subject matter. In Ontario, there is a history of lack of representation and misrepresentation of black students and their identities, and a continued anti-black racism that is embedded in the educational system (JAMES \& TURNER, 2017; MAYNARD, 2017). However, the discourses of multiculturalism fueling educational decisions often prevent educators from addressing critical issues like racism in educational contexts. "Through celebration and song, and with no need to mention racial differences, discourses of multiculturalism make their way into acceptable curricular practice (SCHICK \& ST. DENIS, 2005, p. 304).

In 1997, Dei et al. conducted a critical ethnography focused on the narratives of black youth and school drop-outs in the public school system in Ontario. 
They conducted a critical ethnography to ensure they captured comprehensive data that could represent the complexities of the black youths' experiences. These youth spoke to their disillusionment with the Eurocentrism of the curriculum content. Dei et al., explain that the intent of the study was to develop a wholistic understanding of student disengagement informed by the "students' narratives of their lived experience," which the choice of critical ethnography made possible.

The main research objective was the investigation of what students' narratives of their lived experiences could tell us about the drop-out problem, and particularly about the influence of race/ethnicity, class, gender, power, and social structures on dropping out from school. The study, therefore, sought to examine all of the possible factors related to student disengagement, with the focus on what can be done to solve these problems and make schools work for all youth (1997, p. 6-7).

In 2017, more than two decades later, James and Turner (2017) present findings of research that echo what black youth and others said more than two decades earlier. This report is based on a community-led initiative that involved extensive qualitative data collection. The research captured ".. the issues from the perspective of Black community members, parents, students, and educators" (p. 4). The hope is that the multitude of perspectives and voices shared have contributed to a report that will serve a number of purposes.

[...] we hope that it will be used by Black communities as a tool to advocate for changes within the Ontario Ministry of Education as well as their local school boards.... [to use]this report and the recommendations we offer to create immediate change and also as a starting point for further conversation and research (JAMES \& TURNER, 2017, p. 4).

Critical qualitative research has the potential to do as James and Turner describe including providing findings that black communities can use as a tool to advocate for change to policy makers and recommendations that can inform decisions regarding research important for the future of black students and their communities.

In James and Taylor's (2008) qualitative study with postsecondary students, they collected multiple sources of qualitative data, which included: “... 
application statements, data collected during weekly, common hour sessions, individual life history interviews, and personal journals kept specifically for the purpose of the research." (p. 572). They described the narratives constructed through the data representation as providing a view, "of how their [participants] marginalized position as ethnic and racial minority, working-class, immigrant, and second-generation individuals contributes to the complex challenges they faced in university [...]" (JAMES \& TAYLOR, 2008, p. 573).

Many marginalized youth, who identify in multiple ways and are ascribed identities based on race, class, and other socially constructed characteristics, struggle to access and to complete postsecondary programs. Critical research into the experiences of marginalized youth, who are trying to access and be successful in postsecondary education is essential for arguing for change with policy makers. Sometimes words can speak to the heart of the matter, more than numbers.

Many of the supporters of multicultural education in Canada are focused on efforts to broaden the curriculum but this continues to happen as a surface strategy. Studies of curricular initiatives such as inclusion of Black History month, a specific month dedicated to black history, in schooling contexts, have received considerable criticism for their quick fix to a complex and serious problems. An antiracism framework for education has garnered much support from critical camps of educators and educational researchers who engage in qualitative research and critical race analysis (DEI, 2000; ST. DENIS, 2007). They appreciate what a shift from an emphasis on multicultural education to antiracism education accomplishes:

The shift from multicultural education to antiracism education is from a preoccupation with cultural difference to an emphasis on the way in which such differences are used to entrench inequality. Antiracism education draws attention to the difference between the rhetoric of multiculturalism and its practice. The prime concern of antiracism initiatives is with systematic discrimination in all its manifestations, ranging from the treatment of minorities in history to the hidden curriculum of schools (MOODLEY, 2001, p. 812).

Qualitative research, with a critical race theoretical perspective embedded, disrupts the liberal multicultural flow by introducing the voices of those who experience a lack of representation, or worse, a mis-representation of their knowledge and culture in the curriculum. 
Quantitative data can help identify the demographics of youth leaving educational contexts before successfully completing their programs. In more recent years, the hard-fought battle to collect race-based data from some school-boards, has been rewarded (JAMES \& TURNER, 2017). These data are useful to knowing specifically how many black and racialized and Indigenous youth are progressing or not through the educational system and documenting the role race may play in issues related to equity in education. However, participant and community voices are missing from this data which precludes capturing the complexities represented in articulations of experience. The data produced do not represent the nuances of the experience of those who struggle to access and successfully complete public school and postsecondary education and are limited in their value to inform educational policy decisions.

\section{Colonialism and Indigenous students}

In the last few decades, an emphasis on understanding the effects of colonization and oppression on First Nations people in Canada, in relation to education, has gained momentum. In particular a critical postcolonial lens has been aimed at curricular knowledge and power relations embedded in educational systems.

The transmission of knowledge through the education system has been built on the foundation of historical and societal ideology; however, reflecting on the education system brings to light questions such as, whose culture is predominant within the curriculum? What is the principal perspective reflected in the course content? Most importantly, whose history, values, and beliefs are absent from or marginalized by the existing system? (VINDEVOGHEL, 2016, p. 88).

Critical research makes visible the limitations of a multicultural perspective, its surface attempt to diversify the curriculum and its overreliance on and privileging of Eurocentric knowledge (DION, 2009; ST. DENIS, 2007). This research is instrumental in addressing the questions that Vindevoghel articulates above, as well as other questions that have similar intentions.

In K-12 and postsecondary education, there is a lack of historical knowledge that addresses the past and continuing colonization of Indigenous 
students and peoples (COTE-MEEK, 2014). In 2018, non-Indigenous students, in schools and universities, can still be found who have no knowledge of the colonial residential school system, the Canadian Government forced on First Nations peoples (BATTISTE, 2013). "[...] one of the major issues in the history of education in Canada - the residential schools and the education of the Aboriginal Peoples - brings to the fore memory, remembrance, and trauma [...]". (BRUNO-JOFRE, 2014, p. 784).

Indigenous and non-Indigenous researchers conducting critical qualitative research have worked closely with white teachers to engage in deliberation regarding curriculum content and pedagogies and the grave impact they both can have on the experiences of Aboriginal students. Dion (2009) expresses her desire to disrupt the representations of Aboriginal people in school curriculum: "I recognize the constraints of teaching and learning within the structures of the classroom but also recognize the possibilities for, and have a desire to transform, the ways in which Aboriginal people are remembered and (re)presented in the school curriculum" (p. 13). Dion (2009) conducted an empirical study during which she worked closely with white teachers in classroom contexts using the Braiding Histories Stories, post-contact history texts from Aboriginal perspectives that she and her brother co-authored. She describes her intention to uncover: " $[\ldots]$ the issues and challenge that educators confront when they take up the task of teaching and learning from Aboriginal subject material" (p. 13).

Indigenous researchers are conducting critical qualitative research using a variety of interpretivist methods and methodologies including Indigenous, participatory and community-based approaches. A cluster of issues is at the center of this critical qualitative research, which highlights the Indigenous struggles for their rights to a fair and just education.

Schools continue to colonize Indigenous students through the valuing of Eurocentric knowledge and the exclusion of other knowledge, including Indigenous. Rather than supporting multicultural education, Indigenous scholars and others have been asking for a decolonization of curriculum and pedagogy. Currently there is a growing recognition of the importance of listening to the perspectives of Indigenous students and communities: "It is so vitally important that those who work in spheres that deal with knowledge and education listen to insights of colonized peoples-the victims of Western scientific universalism" (KINCHELOE, 2008, p. 6).

Although there is some evidence of support of critical qualitative research for decolonizing purposes, advancing it in practice will be difficult. Educational researchers need to remain alert to the ways in which such research is diminished in neoliberal contexts. For example, in a case where qualitative research served as a basis for reporting on Aboriginal access to postsecondary education, 
it was clear that this methodological choice was seen as inferior compared to the collection of quantitative "outcome" data:

It should be noted that the research compiled in this report is largely qualitative. There is widespread agreement among the stakeholders interviewed that these types of programs are valuable; however, there was a distinct lack of outcome data available to allow the researchers to state that the programs reviewed had a "measurable" and positive impact on Aboriginal students' postsecondary success. Nevertheless, where student outcomes were measured, the results were promising. Despite the lack of quantitative evidence to support the impact of the programs, the researchers were able to infer that progress has been made on. (MALATEST \& ASSOCIATES LTD, 2010, p. 8)

Hope for change has come from the work of the Truth and Reconciliation Commission that published its report and recommendations in 2015. This Commission heard from 6000 witnesses. Indigenous peoples spoke of their traumatic experiences in hopes of finding justice and changing the colonizing practices that continue today, in various forms, in Canadian educational systems:

Canada's residential school system for Aboriginal children was an education system in name only for much of its existence. These residential schools were created for the purpose of separating Aboriginal children from their families, in order to minimize and weaken family ties and cultural linkages, and to indoctrinate children into a new culture- the culture of the legally dominant Euro-Christian Canadian society [...] (TRUTH AND RECONCILIATION COMMISSION OF CANADA, 2015, p. 5)

As a result of the findings and recommendations of the Commission ministries of education, educational administrations and educators, school boards and universities, are being pressured to make changes in the system. The earlier and continued calls for decolonizing schools and academic institutions has found some support that was not there previously. Only time will tell if the recommendations will move from pages in a document to actual places and influence the lives of current and future Indigenous, children, youth and peoples.

It is clear, however, that movement will need to be supported by research from a broad and critical perspective that is informed by experiential and local 
knowledge. Bruno-Jofre suggests that: "A transnational and trans temporal perspective, with the help of postcolonial methodologies but without neglecting location, would help to create a new map of knowledge of the 'educational' experience of Aboriginal peoples” (BRUNO-JOFRE, 2014, p. 784).

\section{Challenges moving forward}

The persistence of the neoliberal influence, within and outside of educational contexts, is one of the greatest challenges to supporting the use of critical qualitative methodologies and methods in educational research and to advancing social justice and equity in education.

Post-positivist research designs and quantitative research and data collection continue to thrive in the context of the Canadian neoliberal university. The role and influence of quantitative research has not diminished in research in education, particularly research that informs educational policies and policy makers, but has gained momentum in the return of a growing emphasis on accountability and outcomes-based education. The reliance on large quantitative databases continues. The implementation of standardized testing across provinces and territories, a very expensive endeavor, is supported by ministries of education, government and institutional administrations. Funds are expended to ensure necessary quantitative data are produced to compare and contrast degree of student success across the country. Provincial and national discipline-specific testing systems are in place to assess Canadian children and youth and their academic achievement (VOLANTE, FAZIO \& RITZEN, 2017). Large databases are seen as fiscally responsible ways to measure educational outcomes and to create "good" policy. "Neo-liberal economic ideologies and their spawn, managerialism, have demanded that practice and policy be assessed in terms of fiscal accountability and little else" (BROWN \& STREGA, 2005, p.5).

The neoliberalism embedded in Canadian institutions also influences Canada's interactions with other countries as globalization of education intensifies. Canada contributes to the proliferation of international surveys that measure, compare and contrast student learning outcomes across countries and continents. Volante, Fazio \& Ritzen (2017) state that:

Over the past 50 years, the Organization for Economic Cooperation and 
Development (OECD) has increasingly influenced the nature and scope of education policies in primary, secondary, and tertiary sectors around the world. Policy suggestions in these sectors primarily stem from the results of their various international surveys such as the Programme for International Student Assessment (PISA) [...] (p. 34).

Sellar \& Lingard (2018) explain: "The focus [of large databases] is most often comparative performance on the test, as reflected by national ranking, and consideration of performance against OECD average scores, with a tendency to neglect equity issues raised by the data" (p. 367). Equity issues are not the focus of the exercise, comparing scores takes precedence.

Quantitative research continues to contribute useful data to policy makers and educators producing results that speak to national and global contexts. This research has provided data necessary to generalize across local and global contexts. Positivist and post-positivists designs continue to provide statistical and more sophisticated quantitative data that keep the global connections operating. Critics of globalization, pointing to Western imperialism continuing to assert itself globally, emphasize the dangers of creating a universal global curriculum and standardized curricula. In Canada the push to standardize across provincial and territorial spaces is also met with resistance. However, the desire of educational authorities, operating within a neoliberal milieu, to produce statistical and sophisticated quantitative data to measure educational outcomes, to support governmental decisions about education nationally and globally, continues.

Although the usefulness of qualitative research in educational contexts is not as contested as in earlier years, challenges in conducting qualitative research in educational contexts, postsecondary and otherwise, persist. Critics might heed Torrance's (2011) argument that: “...it is qualitative research that is best placed to recover and advance new forms of science and government, precisely because it rests on direct engagement with research participants" (p. 578).

Money is also a challenge in advancing critical qualitative inquiry. In Canada, national competitions for research funding are in place. However, more funds are available to faculty members in the "pure" sciences than to the social science researchers (SSHRC). Empirical qualitative research is expensive and labor intensive. In universities, funding models that reflect good business practice are in operation and are used to argue against institutional authorities providing qualitative researchers the large amounts of money necessary to explore complex educational issues, even when funders are aware of the potential of critical qualitative research has to offer. Findings from research exploring social justice and equity issues in education call for additional funding for educational 
research, not a decrease in the sparse funding already available. K-12 systems as well as the postsecondary realm are feeling the effects of neoliberal policy decisions that have negative implications for their finances.

Critical qualitative research programs face challenges because of their lengthy timelines in a context where time equates with money. Complications arising from institutional ethics review of qualitative research specifically, are well documented as are the unforeseen ethical issues that arise and must be addressed as the research progresses (TILLEY, 2016). Researching with marginalized and vulnerable research participants add an additional layer of complexity that equates to the need of more time and more funding.

In the past few decades, academics working in education have been pushed to move out of their ivory towers and to connect to the community at large, especially to those communities and members who work for, and are concerned about, the education of youth and children. A challenge for these researchers, who see their responsibilities to remain connected to schools, is the complexities of researching with teachers in their schooling contexts or supporting teachers to conduct inquiry into their curricular and pedagogical practices. Working out collaborations between teachers and school administrators and faculty researchers may not be accomplished easily especially if the research is focused on critical socio-cultural questions that critique policies and systems (TILLEY, POWICK-KUMAR \& RATKOVIC, 2009).

Student research also reflects this qualitative turn as many students (in education) are drawn to the interpretivist paradigm to design studies as part of their graduate program requirements. Based on past history, there is no reason not to expect a continuation of the proliferation of qualitative methodologies and methods. Preparing graduate student researchers continues to be a challenge as the need for researchers with understandings of the interpretivist, qualitative paradigm keeps growing. In terms of graduate student research training, the next generation may also receive push back from within an expanding neoliberal context as they contribute to developing a new landscape of methodologies and methods to address ever-growing complex issues in education.

\section{Conclusion}

The efforts to engage in social justice and equity work in education will continue. In Ontario, some movement to provide support for this work is happening: "Ontario recently established the Anti-Racism Directorate and the 
Minister Responsible for Anti-Racism, recently tabled legislation that would enable the provincial government to mandate data collection and anti-racism impact assessments in various sectors, including education" (JAMES \& TURNER, 2017, p. 2).

The release of the Black Experience Project, which reported on the experiences of black youth and communities, will highlight the role of critical qualitative research in understanding the experiences of black students specifically, but also the importance of critical research to understanding socio-cultural and educational issues in the Canadian context. Critical qualitative research is needed to inform any new directions in educational policies that affect marginalized populations who have for many years lived with the dominant group voice fueling most of the important educational decisions.

Through the use of qualitative methodologies and methods and the application of postmodern, postcolonial critique, educational researchers have been able to explore critical questions about the inequities in education that continue into the 21 st century. We will need to continue to find the best possible methodologies and methods to suit the growing complexities of the questions that are emerging. It is clear those questions will not become simpler as we conclude this decade.

Ethnic, racial, cultural, linguistic, and religious diversity is found in nations around the world. ...educational challenges experienced by Indigenous and ethnic groups in Peru, Cuba, Brazil, and Mexico...educational challenges and reform related to diversity in South Africa and the Francophone nations in Africa. (BANKS, 2009, p. 10)

Although this paper is offering a Canadian perspective, the author expects commonalities will exist across local and global contexts. Dominant groups that exercises power will be in place across all populations. There will always exist those who live in the shadow of privilege. Critical qualitative research is a tool for those who want to work with, and for, marginalized students and communities who have a right to a just and equitable education. 


\section{Acknowledgements}

I would like to thank Leanne Taylor who read drafts of the manuscript and offered helpful feedback that enhanced the final version of this paper.

\section{REFERENCES}

Banks, J. K. (2009). Multicultural education: Dimensions and paradigms. In J. A. Banks (Ed.), The Routledge International Companion to Multicultural Education (pp. 9-32). New York: Routledge.

Battiste, M. (2013). Decolonizing education: Nourishing the learning spirit. Vanouver, BC: UBC Press.

Brown, S. \& Strega, S. (2005). Transgressive possibilities. In L. Brown and S. Strega (Eds.). Research as resistance: Critical, Indigenous, \& anti-oppressive approaches (pp.117). Toronto, ON: Canadian Scholars' Press.

Bruno-Jofre, R. (2014). History of education in Canada: Historiographic "turns" and widening horizons. Paedagogica Historica, 50 (6), 774-785.

Cote-Meek, S. (2014). Colonized classrooms: Racism, trauma and resistance in Post-secondary education. Fernwood Press: Halifax, NS. Canada.

Dei, G. J.; James, I. M.; Karumanchery, L. L.; James-Wilson, S. \& Zine J. (2000). Removing the margins: The challenges and possibilities of inclusive schooling. Toronto, ON, Canada: Canadian Scholar's Press.

Dei, G. J. \& Mazzuca, J.; Mcisaac, E. \& Zine, J. (1997). Reconstructing 'Drop-out: A critical ethnography of the dynamics of Black students' disengagement from school. Toronto, ON: University of Toronto Press.

Denzin, N. K. (2003). Performance ethnography: Critical pedagogy and the politics of culture. Thousand Oakes, CA: Sage.

Denzin, N. K. \& Gardiana, M. D. (2006). Qualitative inquiry and the conservative challenge. Left Coast Press: Walnut Creek, California.

Denzin, N. K. \& Lincoln, Y. S. \& Tuhiwai Smith. (2008). (Eds.) Handbook of critical and Indigenous methodologies. London: Sage.

Denzin, N. K., \& Lincoln, Y. S. (2005). (Eds.). (3rd ed.). The Sage handbook of qualitative research. London: Sage. 
Denzin, N. K., \& Lincoln, Y. S. (2011). (Eds.). (4th ed.). The Sage handbook of qualitative research. London: Sage.

Dion, S. (2009). Braiding histories: Learning from Aboriginal people's experiences and perspectives. Vancouver BC: UBC Press.

Foucault, M. (1980). “Prison Talk”. In Colin Gordon (Ed.), Michel Foucault: Power/ Knowledge, selected interviews, 1972-1997, (pp. 37-54). Brighton, UK: Harvester Press.

Gallagher, K. (2008). (Ed.). The methodological dilemma: Critical, creative and Post-positivist approaches to qualitative research: New York: Routledge.

Ghosh, R. \& Abdi, A. (2013). (2nd ed.). Education and the politics of difference. Canadian Scholars' Press: Ontario, Canada.

Ginwright, S. (2008). Collective radical imagination: Youth participatory action research And the art of emancipatory knowledge. In J. Cammarota \& M. Fine (Eds.), Revolutionizing education: Youth Participatory action research in motion (pp. 13-22). New York, NY: Routledge.

Goetz, J. P. \& Lecompte, M. D. (1984). Ethnography and qualitative design in educational research. Academic Press: Orlando, Florida.

Hamera, J. (2011). Performance ethnography. In Denzin, N. K. \& Lincoln, Y. S. (Eds.). (4th ed.). The Sage handbook of qualitative research. London: Sage.

Hammersley, M. (1990). Classroom ethnography: Empirical and Methodological Essays. Toronto, ON.: OISE Press.

Hinchey, P. H. (2010). Finding freedom in the classroom: A practical introduction to critical theory. Peter Lang Publishing: New York.

James, C. \& Taylor, L. (2008). Education will get you to the station: Marginalized students' experiences and perceptions of merit in accessing university, Canadian Journal of Education, 31(3), 567-590.

James, C. E. \& Turner, T. (2017). Towards Race Equity In Education: The Schooling of Black Students in the Greater Toronto Area. Toronto, Ontario, Canada: York University.

Jardine, C. G. \& James, A. (2012). Youth researching youth: Benefits, limitations and ethical considerations within a participatory research process. International Journal of Circumpolar Health, 71, 1-9.

Joshee, R. (2009). Multicultural education policy in Canada: Competing ideologies, interconnected discourses. In J. A. Banks (Ed.), The Routledge International Companion to Multicultural Education, 96-108. New York: Routledge.

Kapoor, D.; Jordan, S. (2009). (Eds.). Education, Participatory Action Research, and Social Change: International Perspectives. New York: Palgrave\& Macmillan.

Kincheloe, J. (2008). Introduction: What We Call Knowledge Is Complicated and Harbors 
Profound Consequences. Knowledge and critical pedagogy: An introduction (pp. 3-25). Dordrecht, London: Springer.

Kindon, S.; Pain, R. \& Kesby, M. (2010). (Eds.), Participatory Action Research Approaches and Methods: Connecting People, Participation and Place (pp. 9-18). London: Routledge.

Lagemann, E. (2000). An elusive science: The troubling history of educational research. Chicago: University of Chicago Press.

Levine-Rasky, C. (2012). Whiteness: Normalization and the everyday practice of power. In D. Brock, R. Raby \& M. P. Thomas (Eds.) Power and Everyday Practices (pp. 86109). Toronto, ON: Nelson Education Ltd.

Lincoln, Y. S. \& Cannella, G. S. (2004). Dangerous discourses: Methodological conservatism and governmental regimes of truth. Qualitative Inquiry, 10(1), 5-14.

Lincoln, Y. S. \& Guba, E. G. 1985. Naturalistic Inquiry. Newbury Park CA: Sage Publications.

Lincoln, Y. S.; Lynham, S. A. \& Guba, E. G. (2011). Paradigmatic controversies, contradictions, and emerging confluences, revisited. In N. K. Denzin \& Y. S. Lincoln, (Eds.). (4th ed.), 97-128. The Sage handbook of qualitative research. London: Sage

Loutzenheiser, L. W. (2007). Working alterity: The impossibility of ethical research with youth. Educational Studies, 41(2), 109-127.

Lund, D. E. (2003). Educating for social justice: Making sense of multicultural and antiracist theory and practice with Canadian teacher activists. Intercultural Education, 14 (1), 3-16.

Malatest, R. A. \& Associates LTD. (2010). Promising practices: Increasing and supporting participation for Aboriginal students in Ontario. Toronto: Higher Education Quality Council of Ontario. Canada

Maynard, R. (2017). Policing Black lives: State violence in Canada from slavery to present. Halifax, NS, Canada: Fernwood press

Mcmurtry, R. R. (2009). The roots of youth violence in Ontario Report. Education Law Journal, 19(1), 35-39.

Moodley, K. A. (2001). Multicultural education in Canada: Historical development and current status. In JA Banks \& CA McGee Banks (Eds.), Handbook of Research on Multicultural Education, pp. 801-820, California: Josey-Bass.

Page, R. (2000). The turn Inward in qualitative research. Harvard Educational Review, $70,19-25$

Paul, J. L. and Marfo, K. (2001) Preparation of educational researchers in philosophical foundations of inquiry. Review of Educational Research, 71(4), 525-547. 
Picower, B. (2011). Resisting Compliance: Learning to Teach for Social Justice in a Neoliberal Context. Teachers College Record113(5), pp. 1105-1134

Prasad, P. (2005). Crafting Qualitative research: Working in the Postpositivist Traditions. New York: M. E. Sharpe, Inc. SAWYER, R. \& NORRIS, J. (2015). Duo ethonography: A retrospective 10 years after. International Review of Qualitative Research, 8(1), 1- 4.

Researching how cash transfers impact communities in Sindh, Pakistan: Q\&A with REFANI-Pakistan's Qualitative Researcher. (2016). Retrieved from: https://www. actionagainsthunger.org/sites/default/files/publications/Zubaida_Metlo_Interview.pdf. Access in: Jun. 12, 2019.

Schelbe, L.; Chanmugam, A.; Moses, T.; Saltzburg, S.; Williams, L. \& LETENDRE, J. (2015). Youth participation in qualitative research: Challenges and possibilities. Qualitative Social work, 14(4) 504-521.

Schick, C. \& ST. Denis, V. (2005). Troubling national discourses in anti-racist curricular planning. Canadian Journal of Education28(3), 296-317.

Sellar, S. \& Lingard, B. (2018). International large-scale assessments, affective worlds and policy impacts in education. International Journal of Qualitative Studies in Education, 31(5), 367-381

Sethi, B. (2014). “A Grand Erie Photovoice Community Report 'Do You See What I See?' Community-based Participatory Research with Immigrant/Refugee KAAJAL Women using Photovoice." 1- 40.

Smith, D. E. (2005). Institutional ethnography: A sociology for people. Altimira Press: Oxford, UK.

St. Denis, V. (2007). Aboriginal education and anti-racist education: Building alliances across cultural and racial identity. Canadian Journal of Education, 30(4), 1068-1092.

Suleiman, A. B.; Soleimanpour, S.; \& London, J. (2006). Youth action for health Through youth-led research. Youth Participation and Community Change, 14(1-2), 125-145.

Tilley, S. A. (1998). Becoming familiar: Exploring stories of schooling with women in prison. Unpublished doctoral dissertation, Burnaby, BC, Canada: Simon Fraser University.

Tilley S. A. (2016). Doing Respectful Research: Power, Privilege and Passion. Halifax, NS, Canada: Fernwood Press

Tilley, S. A. (2006). Multicultural practices in educational contexts: Addressing diversity and the silence around race. In D. Zinga (Ed.), Navigating Multiculturalism: Negotiating Change, 142-159. Newcastle, UK: Cambridge Scholars Press.

Tilley, S. A.; Powick-Kumar, K. D. \& Ratković, S. (2009). Regulatory Practices and School-based Research: Making Sense of Research Ethics/Review [52 paragraphs]. Forum Qualitative Sozialforschung / Forum: Qualitative Social Research, 10(2), Art. 32. Retrieved from: http://nbnresolving.de/urn:nbn:de:0114-fqs0902326. Access in: May 24, 2019. 
Tilley, S. A. \& Powick, K. D. (2015) “Radical stuff”: Starting a conversation about racial identity and white privilege. In P. Carr \& D. Lund (Eds.), (2nd Edition). Revisiting the great white north? Reframing whiteness, privilege, and identity in education in Canada, (pp. 125-139). Rotterdam, The Netherlands: Sense.

Torrance, H. (2011). Qualitative research, science, and government: Evidence, criteria, policy and politics. In N. K. Denzin\& Y. S. Lincoln, (Eds.). (4th ed.), The Sage handbook of qualitative research, (pp. 569-580). London: Sage

Truth and Reconciliation Commission of Canada. (2015). Honouring the truth, reconciling For the future: Summary from the final report of the Truth and Reconciliation Commission of Canada. Retrieved from http:/www.trc.ca/websites/trcinstitution/ File/2015/Honouring_the_Truth_Reconciling_fo r_the_Future_July_23_2015.pdf. Access in: May 24, 2019.

Verkuyten, M. (2003). Racism, happiness and ideology. In H. Van Den Berg, M. Vetherell and H. Houtkoop-Steenstra (Eds.), Analyzing race talk: Multidisciplinary perspectives on the research interview, 138-155. Cambridge, UK: Cambridge University Press.

Vindevoghel, L. J. (2016). Power, Identity and the Construction of Knowledge in education. in education, 2(2), 87-97

Volante, L.; Fazio, X. \& Ritzen, J. (2017). The OECD Educational policy reform: International Surveys, Governance, and policy evidence. International Journal of Educational Administration and Policy, 184, 34-48.

Yon, D. A. (2000). Elusive Culture: Schooling, Race, and Identity in Global Times. Ithaca, N.Y.: State University of New York Press.

Text received on May 10, 2019.

Text approved on May 17, 2019. 